\title{
Cuaderno: gritos en la época del desierto
}

\author{
Por Juan Manuel González Sequeda ${ }^{1}$ \\ Universidad de Cartagena
}

\begin{abstract}
Cuaderno. Revista del Taller de Escritura creativa Coloquio, $\mathrm{n}^{\circ} 1$ (Marzo-Junio), Cartagena, Editorial Universitaria de la Universidad de Cartagena, 58p.
\end{abstract}

Cuaderno es la primera muestra en letra impresa del trabajo literario que se ha gestado, desde hace algún tiempo, al interior de la Universidad de Cartagena en el Taller de Escritura Creativa "Coloquio". Tal como lo anota en la editorial el escritor Raymundo Gomezcásseres, Director del Taller: "El Cuaderno de Coloquio es una mostración que pretende ser demostración de un esfuerzo, de un trabajo. Este primer Cuaderno (esperamos editar dos por año) recoge los textos que después de duras, prolongadas y a veces emotivas jornadas de 'tallereo'

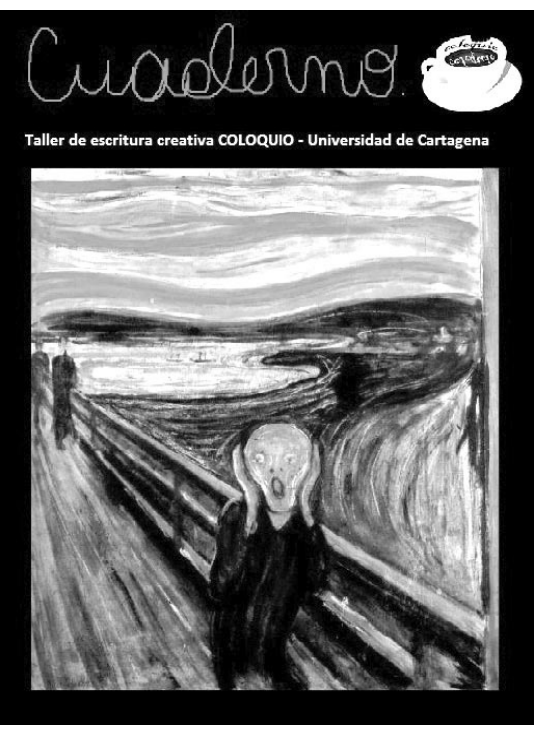
fueron aprobados por los integrantes del grupo".

La apariencia inaugural, sencilla y modesta de Cuaderno, contrasta con el notable nivel artístico que desfila desde su carátula hasta su página final. En las cubiertas observamos a Edvard Munch, con El grito (1893), y a Goya, con El sueño de la razón produce monstruos (1799). Tanto el uno como el otro constituyen simbólicamente a "Coloquio": los gritos son de los integrantes del Taller, quienes apuestan a que en la época del desierto, en la cual estamos, la escritura sea una -tal vez la mejor y más ardua- posibilidad de vivir, puesto que implica enfrentarse a los monstruos producidos por los sueños de la razón.

\footnotetext{
${ }^{1}$ Estudiante del Programa de Lingüística y Literatura de la Universidad de Cartagena. e-mail: juamanuelgonzalesequeda@hotmail.com
} 
Si nos seguimos adentrando en las páginas de Cuaderno, advertimos una revista heterogénea en autores, tópicos, temática e imágenes, y dividida en tres partes. La primera, la ocupa la narrativa; la segunda, la poesía, y la tercera, el ensayo. Al mismo tiempo, nos damos cuenta de que, aun cuando Cuaderno sea un proyecto de unificación del esfuerzo del Taller de Escritura Creativa "Coloquio", no existe (al menos visible) un hilo conductor entre los textos. Este detalle, no obstante, no se traduce en defecto, sino en la cualidad que da fuerza autónoma y única a cada texto, y a sus respectivos autores, quienes se encargan de gritar a su manera el arte escrito y la vida. Cuaderno es un vivo ejemplo de la unidad en la diversidad.

En la primera parte, correspondiente a la narrativa, encontramos a Eduar Ramos Barragán, con "Romeo y Julieta", excelente y macabra reescritura del célebre drama de William Skekespeare; a Jennifer Pérez, con un erotismo desbordado en "Luz"; al autor de las presentes líneas, en "Dora" y "El reo", con una escritura íntima y oral. De igual modo, leemos el fino sensualismo de Xururuca (Leidy de Ávila), el lenguaje calmado y reflexivo de William Hurtado Gómez, las palabras viscerales de Jair Buelvas Caro, entre otros. En la segunda parte, relativa a la poesía, escuchamos, igualmente, los relámpagos de voces líricas como las de Liceth Ruiz o Joaquín Ramírez Jiménez. Y finalmente, en la tecera parte, ensayos y voces que relacionan cine, teatro, literatura y filosofía.

Cuaderno, la primera publicación impresa del Taller de Escritura Creativa "Coloquio", supone el reconocimiento de un grupo de jóvenes estudiantes de la Universidad de Cartagena que se inician en el oficio de escribir, pero, al mismo tiempo, da cuenta del resultado de un trabajo cuyo fin es hablar en la época del desierto, gritar a la vida, gritar sin utilizar la boca, gritar con la literatura como compañera, con sólo un cuaderno y un lápiz. 